\title{
Media Innovation Based on Simple Kit for Dynamic Electricity Learning
}

\author{
*Subkan Nina ${ }^{1}$ \\ ${ }^{1}$ Ministry of Religion Kab. Mojokerto, Madrasah Aliyah Negeri 2 Mojokerto, Mojokerto 61361, East Java, Indonesia
}

\begin{tabular}{|c|c|}
\hline Article Info & ABSTRACT \\
\hline $\begin{array}{l}\text { Article history: } \\
\text { Received October, } 312020 \\
\text { Revised December } 7,2020 \\
\text { Accepted December 29, } 2020 \\
\text { Available Online December 30, } \\
2020\end{array}$ & $\begin{array}{l}\text { This study aims to determine the effectiveness of simple KIT-based } \\
\text { media in improving student learning achievement in dynamic } \\
\text { electricity material. The sample used was the students of class grade } \\
12 \text { of IPA-3 Madrasah Aliyah Negeri } 2 \text { Mojokerto, totaling } 35 \text { students. } \\
\text { The type of research used is research development (Research and } \\
\text { Development). The research data were obtained from questionnaire }\end{array}$ \\
\hline $\begin{array}{l}\text { Keywords: } \\
\text { Simple KIT } \\
\text { Dynamic Electricity } \\
\text { learning achievement } \\
\text { increase } \\
\text { learning outcomes }\end{array}$ & $\begin{array}{l}\text { The questionnaire's responses were as many as } 85.14 \% \text { of students } \\
\text { who thought that the development of KIT-based learning media was } \\
\text { very effective in using dynamic electricity learning. Moreover, as } \\
\text { many as } 14.85 \% \text { think that KIT-based learning media is creative and } \\
\text { interactive learning and is an additional supplement in the teaching } \\
\text { and learning process. From the test results given to students, there was } \\
\text { a significant increase in students' achievements. This indicator can be } \\
\text { seen from the t count value is smaller than the t table ( } \mathrm{t} \text { count }<\mathrm{t} \text { table), } \\
\text { then H1 (learning with media treatment) can be applied in learning. } \\
\text { Another indicator is that the value of p-value is smaller than alpha } 5 \% \\
\text { (0.05) Ho (learning without treatment) is rejected, so it is concluded } \\
\text { that there is a significant increase between learning outcomes before } \\
\text { using Simple KIT-based media after implementing learning media } \\
\text { using simple KIT. }\end{array}$ \\
\hline
\end{tabular}

\section{INTRODUCTION}

In essence, teaching and learning activities are a process of interaction or reciprocal relationship between teachers and students in learning units. The teacher, as a component in the teaching and learning process, has a significant role. The teacher is not just a conveyor of material, but the teacher can be the center of learning more than that.

Teachers have a challenging task to achieve national education goals. The objectives of national education in Law No.20 of 2013 article 3 (Basic, Functions and Objectives of National Education) regarding the National Education System (SISDIKNAS) are as follows: National education functions to develop capabilities and shape the character and civilization of a nation with dignity in order to educate life nation, aims to develop the potential of students so that they become human beings who believe and fear the Almighty God, have a noble character, are healthy, knowledgeable, capable, creative, independent, and become democratic and responsible citizens.

The success of learning objectives is determined by many factors, including the teacher's factor in implementing the teaching and learning process because teachers can directly influence, foster and improve students' intelligence and skills. To overcome the above problems and to achieve the maximum educational goals, the role of the teacher is critical, and it is hoped that teachers will have innovation and be able to use methods or designs in the teaching and learning 
process, namely by choosing learning methods that are innovative, appropriate and following subject concepts. That will be delivered.

As part of education, physics education plays an essential role in improving education quality to produce quality students. Therefore, learning physics needs to be improved. Based on the results of MAN 2 Mojokerto, in general, the learning outcomes of students in physics subjects still need to be improved, which is indicated by $53.75 \%$ of students have not reached the KKM score $(\mathrm{KKM}=71)$. Teaching and learning activities in physics are generally only dominated by a few smart students. It causes low student motivation to follow the physics learning process, especially for students with low abilities, they tend to have a sense of dependence with smart friends, so that individual and classical completeness is still low.

Dynamic electricity is one of the materials in physics lessons that are very much found in everyday life, but in reality, students still have difficulty understanding and solving problems that arise. Therefore, there is a need to increase dynamic electric learning achievement through learning that involves students with innovative learning media and appropriate learning methods and under the subjects' concepts to be delivered.

Learning media can enhance the learning process of students in teaching, which in turn is expected to enhance the learning outcomes they achieve Nana Sudjana (Nana Sudjana, 2009: 2, Safaruddin et al., 2020). Learning media of various types will certainly not be used all of them simultaneously in learning activities. For this reason, it is necessary to select the media. Arsyad (2013: 74, Safaruddin, et al., 2020), explains that the criteria for selecting media come from the concept that learning media is part of the instructional system. So, some of the criteria that need to be considered in selecting right learning media are as follows:

a. In Accordance with Purpose

Instructional media must be selected based on instructional objectives which would be better if it refers to at least two of the three cognitive, affective and psychomotor domains. This is so that the learning media is in accordance with the direction and does not deviate from the goal. Learning media are also not only able to influence aspects of student intelligence, but also other aspects, namely attitudes and actions. Appropriate to Support Material that is Facts, Concepts, Principles, and Generalizations. Not all material can be presented clearly through learning media, sometimes it must be presented in concepts or symbols or something more general and then an explanation is included. This requires special processes and skills from students to understand to analyze the material presented. The selected learning media should be able to be adjusted according to the abilities and needs of students in exploring the content of the material.

b. Practical, flexible, and enduring

The learning media chosen does not have to be expensive and is always technology-based. Utilization of the environment and something simple but effective will be more effective than expensive and complex learning media. Simple and easy to use, affordable and durable and can be used continuously should be one of the main considerations in choosing learning media.

c. Able and Skilled to Use

Whichever medium is chosen. teachers must be able to use these media. The value and benefits of learning media are largely determined by how the skills of teachers use these learning media. The skills in using this learning media can also be passed on to students so that students are also able to skillfully use the selected learning media.

d. Target Grouping

Students consist of many heterogeneous study groups. Of course, between groups will not be the same. For this reason, the selection of learning media cannot be equated, indeed certain universal learning media can still be used, but for more specifically each study group must consider the selection of learning media for each group. Things that need to be considered about student study groups as targets are for example the size of the groups that can be classified into 4, namely large groups, medium groups, small groups, and individuals. The 
general background of each group needs to be considered, such as economic, social, cultural, and others. The learning ability of each student in the group must also be considered to choose which learning media is the right one to choose.

e. Technical Quality

Selection of the media to be used with fragrance meets certain technical requirements. Teachers cannot simply determine learning media even though they have met the previous criteria. Each product that is used as learning media certainly has certain standards so that the product is suitable for use, if the product does not have a specific standard, the teacher must be able to determine the standard for the product so that it can be used for learning media.

Likewise, the learning method or design must be adjusted to the lesson the teacher will deliver. According to Robert M. Branch (2009: 8), states that "Instructional design is an iterative process of planning performance objectives, selecting instructional strategies, choosing media and selecting or creating materials, and evaluation". (Learning design is an iterative process of planning goals, choosing learning strategies, selecting media and selecting or creating materials, and evaluating).

The term learning design should not be something foreign to teachers (read: educators) because a teacher in teaching activities must always pay attention to planning, development, evaluation, and managing the instructional process effectively and systematically so that students succeed in achieving learning goals, as according to Kemp Morrison, \& Ross (1998) in the journal Zehra and Edward (2009: 2046).

Based on the description above, learning physics using SIMPLE KIT-based media is expected to fulfill and make a significant contribution to the shortage of existing media to achieve the expected increase in learning outcomes. In line with this, research conducted by Hartati (2010) states that the use of media/teaching aids in learning can improve students' critical thinking skills. It means that students or learners can more readily accept the learning carried out by the teacher.

Based on the description of the problems above, this study's problem formulation is as follows: How is Simple Kit-Based Media's effectiveness in improving Dynamic Electrical Material Learning?

\section{RESEARCH METHOD}

The type of research used is research development (Research and Development). The research data were obtained from questionnaire responses during learning and the results of the pre-test and post-test.

This questionnaire response is used to determine the teacher's effectiveness in learning using Simple KIT-based media. This test is carried out at the beginning and the end of learning to determine whether student learning outcomes have improved as expected by the researcher (teacher). The score obtained by each student is used to assess the completeness and determine the increase in student learning outcomes in achieving learning indicators.

This study's learning design is the ADDIE development model, a development model consisting of five stages: analysis, design, development, implementation, and evaluation.

The ADDIE development model was developed by Dick and Carry in 1996 to design a learning system (Mulyatiningsih, 2011). This model is used for various product development forms, such as learning strategies, media, and teaching materials. The ADDIE model can guide building tools and infrastructure for training or learning programs that are effective, dynamic, and support training performance itself with several stages (Branch \& Kopcha, 2014). Below is the ADDIE learning system design scheme. 


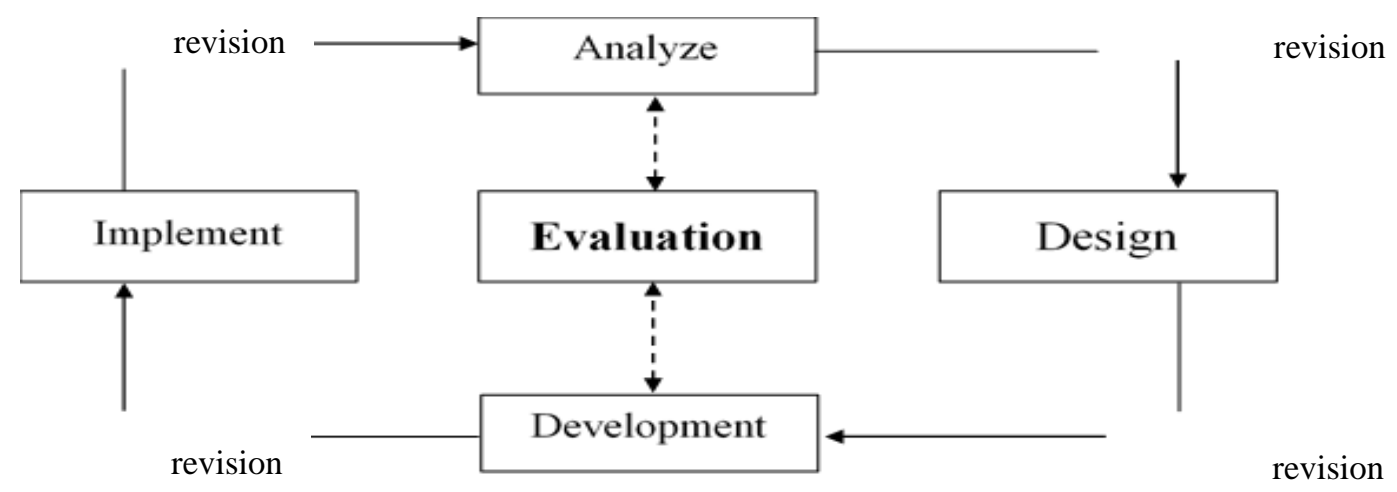

Figure 1. Schematic of ADDIE Model

Table 1. The concepts and procedures for the ADDIE model learning design

\begin{tabular}{|c|c|c|c|}
\hline & Concept & General Procedure & \\
\hline Analyze & $\begin{array}{l}\text { Identify the causes of } \\
\text { problems in learning }\end{array}$ & $\begin{array}{l}\text { 1. Validate learning problems } \\
\text { 2. Determine learning objectives } \\
\text { 3. Confirming the target of students. } \\
\text { 4. Identifying the required sources } \\
\text { 5. Determine financing } \\
\text { 6. Creating a learning management plan }\end{array}$ & 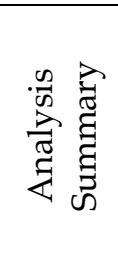 \\
\hline Design & $\begin{array}{l}\text { Verify the desired results } \\
\text { / achievements (learning } \\
\text { objectives) and determine } \\
\text { the appropriate method / } \\
\text { strategy }\end{array}$ & $\begin{array}{l}\text { 1. Inventory tasks } \\
\text { 2. Develop learning objectives } \\
\text { 3. Creating a test method / learning } \\
\text { strategy }\end{array}$ & 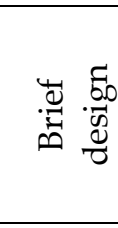 \\
\hline Develop & $\begin{array}{l}\text { Develop and validate } \\
\text { learning resources }\end{array}$ & $\begin{array}{ll}\text { 1. } & \text { Produce content } \\
\text { 2. } & \text { Select or develop supporting media } \\
\text { 3. Develop a guide for students } \\
\text { 4. Develop a guide for teachers } \\
\text { 5. Carry out a trial exam }\end{array}$ & 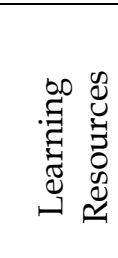 \\
\hline Implement & $\begin{array}{l}\text { Preparation of a learning } \\
\text { environment, and } \\
\text { implementation of } \\
\text { learning by involving } \\
\text { students }\end{array}$ & $\begin{array}{l}\text { 1. Prepare the teacher } \\
\text { 2. Prepare students }\end{array}$ & 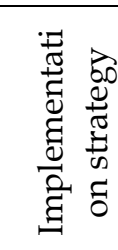 \\
\hline Evaluate & $\begin{array}{l}\text { Assess product quality } \\
\text { and learning process }\end{array}$ & $\begin{array}{l}\text { 1. Determine evaluation criteria } \\
\text { 2. Choose an evaluation tool } \\
\text { 3. Conduct evaluation }\end{array}$ & 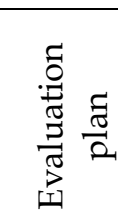 \\
\hline
\end{tabular}

Source: Instructional Design Book of the ADDIE Approach

The ADDIE model of learning design scheme forms a cycle consisting of 5 stages, namely: analysis, design, development, implementation and evaluation.

The Simple KIT design and Materials are as follows: 
1. Simple KIT design

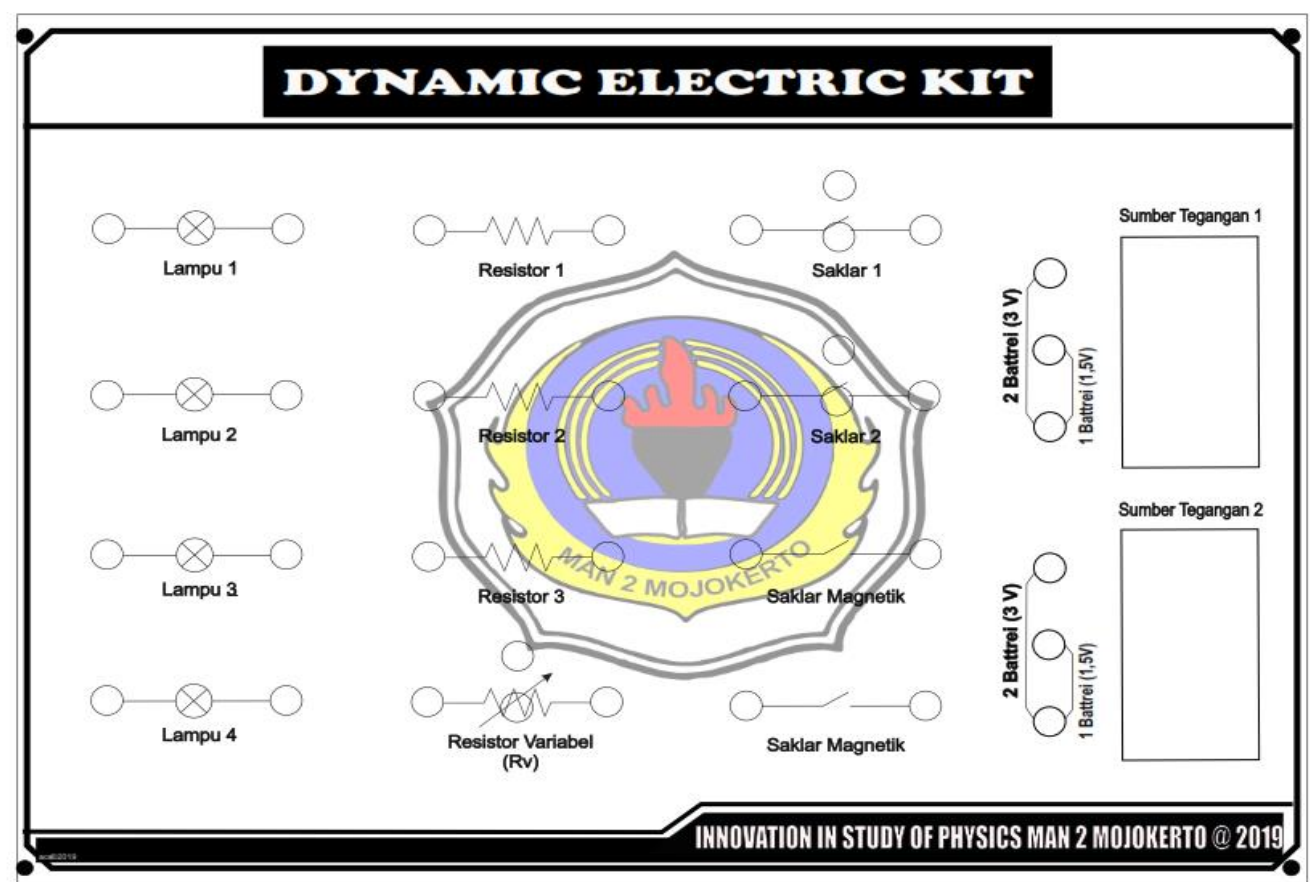

Figure 2. Design of Simple KIT at PKM Department of Physics, Faculty of Mathematics and Natural Sciences, UNESA 2019

2. Simple KIT tools

- Plywood boards approximately $21 \mathrm{~cm} \times 29 \mathrm{~cm}$

- Lights and its fitting as many as 4 pieces

- Cable and crocodile clips 10 pieces (red and black)

- Resistor 10 Ohm 3 pieces

- Resistor variable 1 piece

- Switch 2 pieces

- Magnetic switch 2 pieces

- Batteries 1.5 volts 4 pieces

- Place 2 batteries

- Scroop

- Wooden box for simple KIT

3. Tool Making Procedure

- Prepare a Simple KIT Design

- Combining the simple design of the KIT with the plywood board for the tools

- Punch holes for simple KIT components

- Connect between components with one another

- Testing the connection with each other

- Simple KIT can be used as a dynamic electricity learning medium 


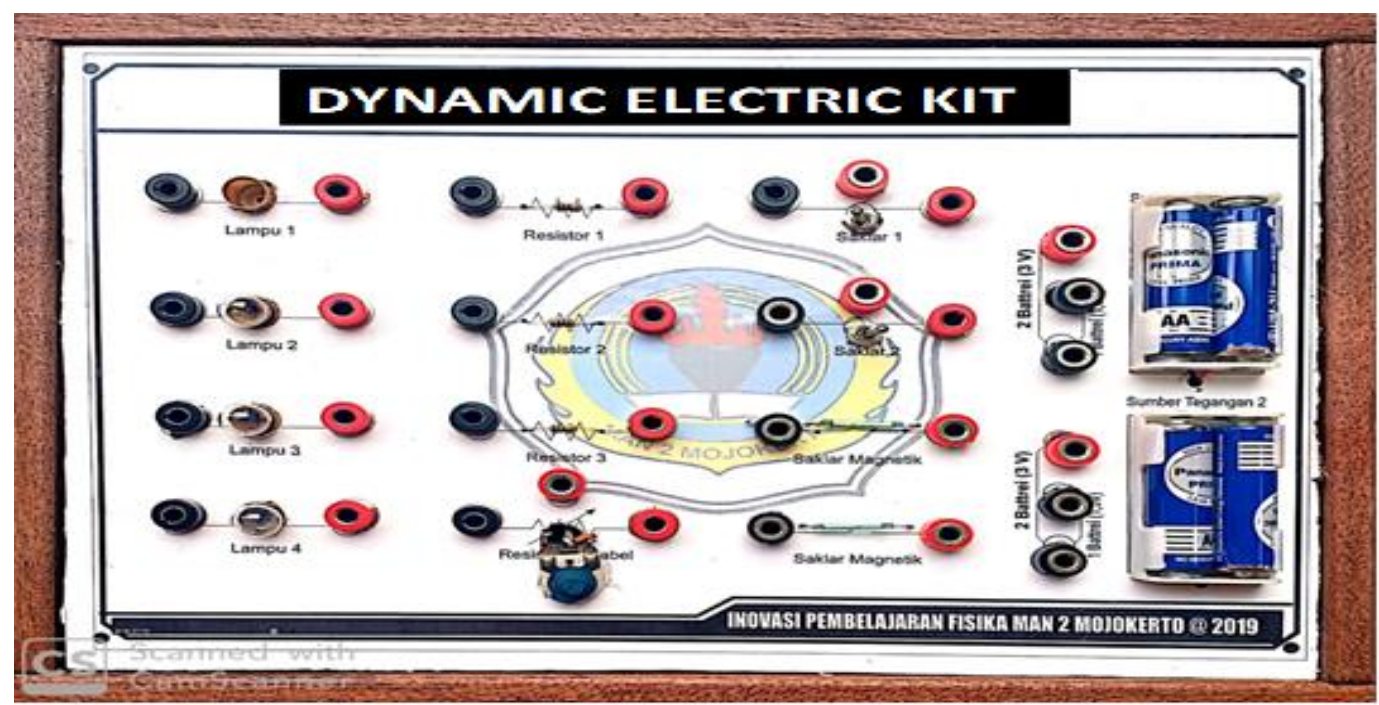

Figure 3. Simple KIT for Learning Media

\section{RESULTS AND DISCUSSION}

Research data:

1. Questionnaire Response Results

Table 2. Questionnaire Response Results

\begin{tabular}{ccccc}
\hline \multirow{2}{*}{$\begin{array}{c}\text { Number of responses } \\
\text { (15 responses times the } \\
\text { number of students) }\end{array}$} & strongly agree & agree & disagree & $\begin{array}{c}\text { totally } \\
\text { disagree }\end{array}$ \\
\cline { 2 - 5 } & 447 & 78 & 0 & 0 \\
\hline \% responses & 85.14 & 14.85 & 0 & 0 \\
\hline
\end{tabular}

From the questionnaire data, it was obtained that $85.14 \%$ of students thought that the development of KIT-based learning media was advantageous in using dynamic electricity learning. Understanding the concepts conveyed by the teacher is more comfortable to accept, learning becomes fun, practical, more concrete and accelerates students to connect lessons with daily applications.

As many as $14.85 \%$ of students thought that KIT-based learning media was creative and interactive learning and became an additional supplement in the teaching and learning process. This fact becomes interesting for teachers because students' responses show a positive value in dynamic electric learning using simple KIT media.
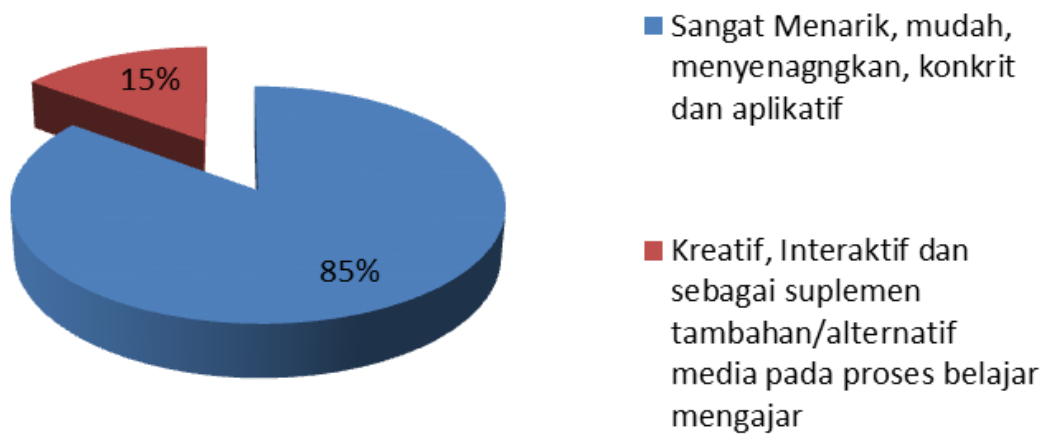

Figure 4. Percentage diagram of the response to the use of Simple KIT media in learning 
2. Pre-Test and Post-Test Value Data

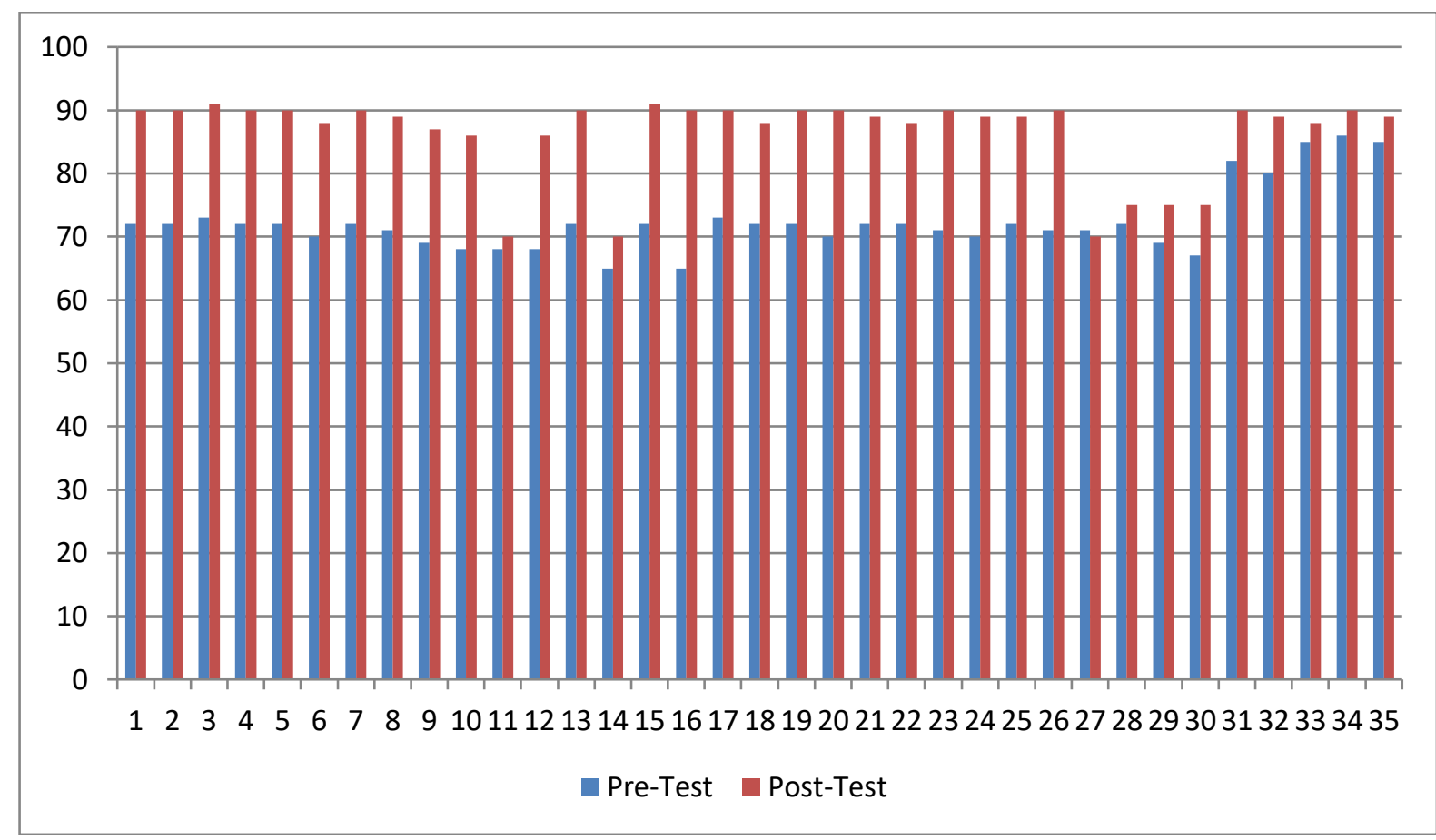

Figure 5. Results of Pre-Test and Post-Test Values

Table 3. $t$-test Results of two samples with different treatments

\begin{tabular}{lrr}
\hline & Pre-Test & \multicolumn{1}{c}{ Post-Test } \\
\hline Mean & 72,37142857 & 86,34285714 \\
\hline Variance & 26,47563025 & 43,2907563 \\
\hline Observations & 35 & 35 \\
\hline Pearson Correlation & 0,355794884 & \\
\hline Hypothesized Mean Difference & 34 & \\
\hline $\mathrm{df}$ & $-12,23017194$ & Degrees of Freedom \\
\hline $\mathrm{t}$ Stat & $2,65447 \mathrm{E}-14$ & Nilai P Value \\
\hline $\mathrm{p}(\mathrm{t}<=\mathrm{t})$ one-tail & 1,690924255 & Nilai T Tabel \\
\hline $\mathrm{t}$ Critical one-tail & $5,30895 \mathrm{E}-14$ & Nilai P Value \\
\hline $\mathrm{p}(\mathrm{t}<=\mathrm{t})$ two-tail & 2,032244509 & Nilai T Tabel \\
\hline $\mathrm{t}$ Critical two-tail & &
\end{tabular}

The statistical test using the t-test found that the average value increased from the Pre-Test of 72.37 to 86.34 on the Post-Test. There is a significant increase in the achievements obtained by students. It is an indicator that the Simple KIT-based learning media can be a medium that can be used by teachers to improve student achievement on dynamic electricity material.

The value of $t$ count is smaller than $t$ table ( $t$ count $<t$ table), this shows that the Simple KITBased Learning Media can improve student learning achievement, so H1 (learning with media treatment) can be applied in learning.

In the table above, it is also seen that the p-value is smaller than alpha 5\% (0.05) Ho (learning without treatment) is rejected, so it is concluded that there is a significant difference between learning outcomes before using Simple KIT-based media and after the application of learning media by using a simple KIT. 


\section{CONCLUSION}

The discussion results were obtained that the Simple Kit Based Media for Dynamic Electricity Learning provides a significant contribution to the teaching and learning process. In response to the questionnaire, as many as $85.14 \%$ of students thought that the development of KIT-based learning media was beneficial in using dynamic electricity learning. Understanding the teacher's concepts is more comfortable to accept, learning becomes fun, useful, and more concrete and accelerates students to connect lessons with daily applications. As many as $14.85 \%$ of students thought that KIT-based learning media was creative and interactive learning and became an additional supplement in the teaching and learning process. From the test results given to students, there was a significant increase in students' achievements. It is an indicator that the Simple KIT-based learning media can be one of the media teachers use to improve student achievement on dynamic electricity material. This indicator can be seen from the $t$ count value is smaller than the $\mathrm{t}$ table ( $\mathrm{t}$ count $<\mathrm{t}$ table) which means that the Simple KIT-based learning media can improve student learning achievement, so H1 (learning with media treatment) can be applied in learning. Another indicator, the p-value is smaller than alpha 5\% (0.05) Ho (learning without treatment) is rejected, so it is concluded that there is a significant difference between learning outcomes before using Simple KIT-based media and after the implementation of learning media using simple KIT.

\section{ACKNOWLEDGEMENTS}

The author would like to thank the students grade 12 of IPA-3 Madrasah Aliyah Negeri 2 Mojokerto who were willing to be a sample in my research.

\section{REFERENCES}

Apriliyanti, D. D., Haryani, S., \& Widiyatmoko, A. (2015). Development of Integrated Science Teaching Aids on the Theme of Mixed Separation to Improve Science Process Skills. Unnes Science Education Journal, 4(2), 836-840.

Bahri, S., \& Zain, A. (1995). Teaching and learning strategies. Bhineka Cipta.

Branch, R. M. (2009). Instructional design: The ADDIE approach. Springer US.

Dewi, I. N. A., \& Prabowo. (2014). Development of mathematical pendulum teaching aids to train students 'process skills on simple harmonic motion material in class XI SMAN 3 Tuban. Journal of Physics Education Innovation, 3(2), 189-194.

Hartati, B. (2010). Development of friction style teaching aids to improve high school students' critical thinking skills. Indonesian Journal of Physics Education, 6(2), 128-132.

Irawan, H. (2016). Increasing motivation and learning achievement using mechanical measuring instruments through mechanical measuring instruments for class $\mathrm{X}$ students of light vehicle engineering. Journal Of Mechanical Engineering Education, 1(2), 179-188.

Jiniarti, B. E., Sahidu, H., \& Verawati, N. N. S. P. (2015). Implementation of problem based learning model assisted by teaching aids to increase activities and physics learning outcomes of class VIII students of SMPN 22 Mataram Academic Year 2014/2015. Journal of Physics and Technology Education, 1(3), 185-192.

Ministry of Education and Culture. (1994). Guidelines for teaching and learning implementation. Balai Pustaka.

Ozdilek, Z., \& Robeck, E. (2009). Operational priorities of instructional designers analyzed within the steps of the ADDIE instructional design model. Procedia-Social and Behavioral Sciences, 1(1), 2046-2050.

Spector, J. M., \& Merrill, M. D., Elen, J., \& Bishop, M. J. (2014). Handbook of research on educational communications and technology. Springer-Verlag.

Safaruddin, Degeng, I. N. S., Setyosari, P., \& Murtadho, N. (2020). The effect of PJBL with WBL media and cognitive style on students' understanding and science-integrated concept application. Jurnal Pendidikan IPA Indonesia, 9(3), 384-395. https://doi.org/10.15294/jpii.v9i3.24628 
Safaruddin, S., Ibrahim, N., Juhaeni, J., Harmilawati, H., \& Qadrianti, L. (2020). The Effect of Project-Based Learning Assisted by Electronic Media on Learning Motivation and Science Process Skills. Journal of Innovation in Educational and Cultural Research, 1(1), 22-29. https://doi.org/10.46843/jiecr.v1i1.5

Sri, A. (2008). Learning strategies in elementary school. Open University.

Subkan. (2019). Smart book for learning physics: Student study guide. CV. MASFIRA.

Sudjana, N. (2009). Teaching media. Sinar Baru Algesindo.

Widiyatmoko. A, (2013). Development of character integrated natural science learning tools using humanistic approaches with cheap learning tools. Indonesian Science Education Journal, 2(1), 76-82.

\author{
Author (s): \\ * Subkan Nina (Corresponding Author) \\ Ministry of Religion Kab. Mojokerto, Madrasah Aliyah Negeri 2 Mojokerto, \\ Mojokerto 61361, East Java, Indonesia \\ Email: subkannina@gmail.com
}

